\title{
PEMELIHARAAN AKIDAH ISLAM: ANALISIS DARIPADA SUDUT PENGUATKUASAAN UNDANG-UNDANG DAN FATWA DI PULAU PINANG
}

SAFEGUARD THE ISLAMIC FAITH: AN ANALYSIS FROM LAW AND FATWA ENFORCEMENT IN PULAU PINANG

\section{Jasni bin Sulong}

Pusat Pengajian Ilmu Kemanusian. Universiti Sains Malaysia. 11800. Pulau Pinang Malaysia.

Emel: jasni@usm.edu.my

\section{Khulasah}

Akidah merupakan tunggak keimanan kepada Allah S.W.T dan Rasul-Nya. Akidah yang utuh bagi seorang Muslim ialah yang melibatkan kepercayaan dengan rukun Iman dan demikianlah sebaliknya. Pada hari ini, ancaman ke atas akidah umat Islam semakin bertambah apabila dunia menjadi semakin terbuka melalui hubungan sosial yang meluas, kemajuan internet dan kemudahan maklumat. Pemikiran yang bercanggah dengan akidah Islam seperti sekular, liberal dan Syiah mula merebak ke atas generasi muda umat Islam. Umat Islam dikelirukan dengan bahan-bahan yang telah diselewengkan dengan memanipulasikan nas syarak. Justeru, kerajaan telah mengambil langkah pro-aktif dengan menggubal undang-undang yang khusus dalam menangani gejala ini. Penanganan ini bukan sahaja melalui tindakan kerajaan melalui langkahlangkah pencegahan pentadbiran ( $\operatorname{sad} z a r a{ }^{\prime} i$ '), tetapi juga berlaku melalui penguatkuasaan undang-undang melalui statut dan fatwa. Justeru, kajian ini bertujuan untuk melihat aspek-aspek akidah yang cuba ditangani melalui statut dan fatwa semasa dalam usaha mengekang ancaman ke atas akidah umat Islam. Skop kajian difokuskan kepada Pulau Pinang 
yang mempunyai komposisi masyarakat Melayu, Cina dan India yang hampir sekata. Kajian ini dilakukan secara kualitatif dengan mengumpul data daripada statut dan fatwa untuk dianalisis secara analisis kandungan. Dapatan kajian menunjukkan bahawa undang-undang telah lama digubal untuk menyekat dakyah songsang ke atas akidah umat Islam. Bagaimanapun, elemen penguatkuasaan menjadi hambatan kepada kesalahan yang berhubung akidah yang masih berlaku terutama melalui medium maya hari ini. Ancaman akidah ini menjadi cabaran kepada umat Islam dan kerajaan untuk terus menerapkan prinsip ajaran tauhid yang sebenar dari masa ke masa.

Kata kunci: Akidah, iman, kesalahan, liberal, undang-undang.

Abstract
Islamic creed is a principal part of faith and devotion
to Allah and His prophet pbuh. The solid creed of a
Muslim was established based on his faith to the sixth
pillar of Iman and vice versa. Nowadays, challenge to
the Islamic creed excelerating due to vast social
interactions, internet links and information facilities.
Indeed, thoughts that against the Islamic creed such
as secular, liberal and Shi'ite are spreading among
our young generations. Muslims are deviated with
fake information by manipulation of certain
individuals towards the Islamic source. Therefore, the
government has taken pro-active steps and regulated
special laws to overcome the problems. The steps
were based on preventive mechanism (sad dharä'i)
as well as an enforcement appliance through statutory
provisions and rulings (fatwā). Hence, the study is at
aim to explore aspects of Islamic creed which is
tackled by law and fatwa in order to prevent the
threats. The scope of study was focusing on Pulau
Pinang which consists of Malays, Chinese and
Indians whom the number of them almost at average.
The study was done qualitatively by gathering data


from statutes and fatwa that were analyzed through content analysis. The study found out that the law has been regulated for many years to prevent deviation of teaching in Islamic creed. However, the sluggish was triggered on the enforcement matter especially where there are many mechanisms at the moment that was manipulate by wrongdoers. Therefore, threats for Islamic creed currently become a paramount challenge for Muslim in this country to follow the right path that was underlined by the prophet pbuh.

Keywords: Islamic creed, faith, wrongdoings, liberal, law.

\section{Pendahuluan}

Islam sangat mementingkan akidah Islam. Akidah adalah perkara pertama yang dibawa oleh Rasulullah s.a.w untuk mengubah kepercayaan masyarakat Arab Jahiliyyah kepada keimanan kepada Allah s.w.t. Keutamaan akidah ini terserlah melalui intipati ayat-ayat Makki yang diturunkan pada tiga belas tahun pertama perutusan Nabi Muhammad s.a.w ketika berdakwah di Mekah. Malahan, kunci kepada anutan agama Islam adalah akidah yang menjadi akar kepada ajaran Islam. Seorang yang rosak akidah boleh membawa kepada kesyirikan dan gugur iman. Manakala orang yang dengan sengaja merosakkan imannya atau menggugurkan akidah boleh dihukum dengan berat dalam Islam melalui kesalahan murtad. Justeru, kajian ini bertujuan untuk membincangkan mengenai keutamaan akidah daripada segi pemeliharaannya sebagai aset utama umat Islam. Penelitian juga akan menelusuri pandangan ulama dan penguatkuasaan undang-undang berhubung pemeliharaan akidah ini di negara ini dengan merujuk khusus kepada praktis di negeri Pulau Pinang.

\section{Akidah dan Pemeliharaan Iman}

Akidah merupakan asas utama dalam keimanan seseorang Muslim. Ia menjadi simpulan ('uqdah) yang kukuh dalam 
hati seseorang umat Islam mengenai keimanan kepada Allah s.w.t dan ajaran Islam yang disampaikan melalui rasul-rasul-Nya. Asas ini dibina berdasarkan kepercayaan dan keimanan dengan hati pada rukun Iman yang meliputi kepercayaan kepada Allah, ${ }^{1}$ kepercayaan kepada Rasul, ${ }^{2}$ kepercayaan kepada Malaikat, $^{3}$ kepercayaan kepada Kitab, ${ }^{4}$ kepercayaan kepada qada' dan qadar $^{5}$ dan kepercayaan kepada Hari Kiamat. ${ }^{6}$ Dalam memastikan seseorang Muslim itu mukmin, mereka dikehendaki mempercayai kepada semua keenam-enam elemen ini tanpa terpilih. Kekurangan satu daripadanya boleh menatijahkan seseorang itu gugur akidah atau tidak beriman.

Tugas Rasulullah s.a.w dalam menyebarkan akidah Islam menempuh rintangan yang tidak mudah. Pelbagai ujian dan tentangan diterima baginda s.a.w dalam menunjukkan kesucian dan kebenaran Islam. Perjuangan ini kemudiannya disambung oleh generasi Sahabat dan Tabien. Islam sebagai agama akidah, menuntut satu tugas besar untuk menyebarkannya dalam kalangan masyarakat iaitu melalui dakwah dan jihad. Berdasarkan jihad, kedaulatan dan kesucian akidah Islam dipelihara daripada diruntuhkan oleh musuh Islam. Di sini, tugas untuk memelihara akidah bukan semata-mata fardu ain ke atas individu, malah juga adalah fardu kifayah yang turut melibatkan masyarakat dan negara. Kandungan Islam adalah nizam atau peraturan yang mengatur kehidupan manusia dengan perintah dan larangan tertentu. ${ }^{7}$

\footnotetext{
${ }^{1}$ Surah al-Ikhlas (112): 1, Surah al-Hujurat (49): 15.

${ }^{2}$ Surah Ibrahim (14): 4.

${ }^{3}$ Surah al-Baqarah (2): 285.

${ }^{4}$ Surah al-Nahl (16): 89, Surah al-Isra' (17): 82.

${ }^{5}$ Surah al-Qamar (54): 49, Surah al-Talaq (65): 2-3.

${ }^{6}$ Surah al-Baqarah (2): 8, Surah al-Zumar (39): 7.

7 Abdul Hadi Awang, Mukaddimah Akidah Muslim (Kelantan: Pustaka Aman Press, 1991), 19.
} 
Oleh kerana itu ia bukan bersifat pilihan dan sukarela semata-mata. Maka sebab itulah Saidina Abu Bakar r.a bertindak memerangi orang yang murtad pada zamannya dan juga pendakwa yang mengaku sebagai nabi. ${ }^{8}$ Tindakan ini menunjukkan ketegasan Islam ke atas kelangsungan akidah Islam di muka bumi ini. Akibat kesungguhan ini, sesetengah masyarakat Barat melabel Islam sebagai agama yang mensucikan perang (holy war), dan mengharuskan pembunuhan serta menumpahkan darah (a religion of the sword). ${ }^{9}$ Walaupun tohmahan ini tidak benar, namun ia menunjukkan kepentingan akidah untuk dipelihara oleh umat Islam dengan jihad dan syariat. ${ }^{10}$

Berdasarkan kepentingan pemeliharaan akidah ini, para pemerintah (umara') dan ulama mempunyai tugas berat dalam memastikan penganut agama sentiasa patuh dan taat pada akidah Islam. Dalam hal ini, ulama dan umara' bukan sahaja menyuruh melakukan perkara yang baik (al-amr bi al-ma'rüf), malah mesti melarang manusia daripada melakukan kemunkaran (wa al-nahy 'an almunkar) dan syirik (al-syirk). Dalam hal ini, tanggungjawab yang dipegang adalah untuk menjaga agama (hifz al-din) daripada kepercayaan yang salah dan sesat.

Oleh kerana itu Sa`id Hawwa ketika mengulas mengenai tugas ulama menyatakan bahawa ulama bertanggungjawab memberi peringatan (inzar) dan menakutkan (takhwif) manusia dengan ancaman azab mengenai soal agama dan penjagaan iman. ${ }^{11}$ Jelasnya,

\footnotetext{
${ }^{8}$ Surah al-Baqarah (2): 217.

9 Choudhury, G. W., Islam and the Modern Muslim World (Kuala Lumpur: WHS Publications Sdn.Bhd., 1993), 1.

10 Abdul Shukor Husin, Ahli Sunah waljamaah Pemahaman Semula (Syarahan perdana Professor: Universiti Kebangsaan Malaysia, 1998), 21.

11 Sa`id Hawwa, al-Asās fī al-Tafsìr (Kaherah: Dār al-Salām, 1985), (10) 122.
} 
persoalan keimanan dan akidah bukan sahaja tamat setelah seseorang menganut agama Islam, tetapi ia hendaklah sentiasa dipupuk dari semasa ke semasa bagi memastikan kelestarian akidah Islam dalam kehidupan seseorang Muslim. Allah s.w.t tidak menerima akidah lain untuk diamalkan selain Islam. ${ }^{12}$

Justeru, terdapat dua langkah yang mesti dilaksanakan dalam memastikan kelestarian pemeliharaan agama (hifz al-dīn) berdasarkan maqāṣid al-syarī ah iaitu: 13

1. Memastikan kewujudan dan kelangsungan agama Islam melalui amalan beragama, pelaksanaan segala syiar Islam menerusi kerja-kerja dakwah dan tazkirah.

2. Membendung pencemaran akidah Islam melalui amar makruf nahi munkar, menghapuskan bid'ah, mencegah murtad dan berjihad di jalan Allah S.W.T.

Justeru, kuasa dan politik juga penting dalam Islam bagi memelihara akidah dan syariat Islam daripada penyelewengan. ${ }^{14}$ Dengan kuasa yang ada, segala perkara yang menjadi keperluan umat Islam dapat direalisasikan termasuklah dalam meneruskan pendidikan Islam (tarbiyyah) berkenaan perkara yang menjadi fardu ain dan fardu kifayah kepada umat Islam. ${ }^{15}$ Tuntutan dua tanggungjawab secara individual dan kolektif ini akan menjamin kelestarian ajaran Islam yang akan sentiasa hidup subur dalam kalangan penganutnya. Secara tidak

${ }^{12}$ Surah Ali 'Imran (3): 85.

13 Ziad Muhammad Aḥmidan, Maqāṣid al-Sharì ah al-Islāmiyyah (Beirut: Muassasah al-Risalah, 2008), 87-130.

14 Andrew F. March, "The Maqsad of Hifz al-Din: Is liberal religious freedom sufficient for the Shari'ah?," in Islam and Civilisational Renewal. (2) 361.

${ }^{15}$ Ibrāhīm bin Mūsā al-Lakhmī al-Ghirnatì al-Māliki, al-Muwāfaqāt fī Ușūl al-Sharì ah (Kaherah: Dar al-Hadith, 2006), (2) 7. 
langsung ia akan dapat menjadi sekatan daripada anasir yang tidak baik. ${ }^{16}$

\section{Tugas Ulama dan Umara dalam Memelihara Akidah}

Sememangnya peranan ulama umara adalah penting dalam mewujud dan menyusun corak hidup beragama dalam masyarakat. ${ }^{17}$ Mereka bertanggungjawab menanam kepercayaan kepada Allah s.w.t dan rukun-rukun iman yang wajib diimani. Bagi umara dalam mengurus dan menguatkuasakan pentadbiran, undang-undang bukan semata-mata berfungsi untuk menjatuhkan hukuman ('uqūbah), tetapi ia juga penting untuk membendung daripada sesuatu jenayah itu daripada berlaku (wiqāyah). Syariat Islam datang dengan penuh persediaan dalam mengawal dan memelihara akidah Islam sejak awal. Misalnya ayat al-Quran berhubung celaan kepada tuhantuhan orang kafir:

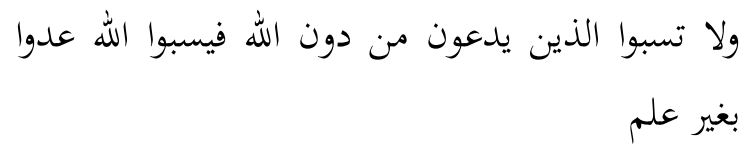

Terjemahan: Dan janganlah kamu memaki sembahan-sembahan yang mereka sembah selain Allah, kerana nanti mereka akan memaki Allah dengan melampaui batas tanpa pengetahuan.

$$
\text { Al-An'am (6):108 }
$$

Larangan celaan ini menunjukkan langkah awal yang diambil oleh Islam sebagai satu bentuk muwāda'ah dan sad al-zari' $a h^{18}$ sebelum berlakunya perbuatan menghina dan mengejek Allah s.w.t dan agama Islam. Langkah ini jelas merupakan kawalan awal sebelum berlakunya

\footnotetext{
${ }^{16}$ March. The Maqsad of Hifz al-Din, 363.

17 Shukri Ahmad, Pengaruh Pemikiran Ulama di Semenanjung Malaysia Akhir Abad ke-20 (Kedah: UUM Press, 2011), 3.

${ }^{18}$ Muhamad bin Ahmad al-Anșārī al-Qurțūbī, al-Jāmi' li Ahkām alQur'ān (Beirut: Dar al-Kutub al-'Ilmiyyah, t.t.), (7) 41.
} 
perkara yang tersebut. Menurut al-Qurțūbi, ${ }^{19}$ ayat ini diturunkan apabila orang kafir Quraisy menyatakan kepada Abi Talib sama ada melarang Nabi Muhammad s.a.w dan sahabatnya daripada menghina dan memarahi tuhan-tuhan mereka atau kami juga akan mencaci tuhannya dan melampaui batas.

Dalam rukun Iman, asas utama akidah yang dibina adalah kepercayaan hati kepada Allah s.w.t. Suntikan iman ini merupakan perkara terpenting di mana ia membezakan seorang yang beriman daripada yang munafik atau zindik. Begitulah seterusnya siri kepercayaan hati dalam rukun iman sehingga umat Islam benar-benar tunduk dan taat pada perintah dan larangan Allah s.w.t. Proses ini melalui pembelajaran atau mendalami ilmu agama (tafaqquh fí al-dìn) sehingga akhirnya mereka menambah iman kepada Allah S.W.T dan menjauhi syirik serta maksiat. Secara tidak langsung, akidah umat akan menjadi kuat dan tidak mudah diseleweng. Kemudian rukun iman dijalin dengan tuntutan rukun Islam yang merupakan praktik daripada kepercayaan hati tadi.

Hasil gabung-jalin ini menjadikan umat Islam memiliki akidah dan amal soleh. ${ }^{20}$ Ia merupakan asas penting yang membentuk keperibadian seseorang insan Muslim. Tanpa akidah, seorang individu akan menjadi rosak dengan kesesatan dan kekufuran. Mereka akan hidup tanpa pedoman Ilāhiyyah dan terlibat dengan syirik. Manakala rukun Islam menzahirkan keimanan dalaman sehingga menonjolkan syiar Islam daripada seorang yang beriman. ${ }^{21}$ Justeru pendidikan adalah penting, malah ulama tradisional akhir abad ke-20 masih meneruskan pendekatan ulama abad ke-19 iaitu pemantapan pemikiran

\footnotetext{
${ }^{19}$ Ibid.

20 ‘Abd Allāh Nāsiḥ 'Ulwān, Muḥādarah Takwīn al-Syakhșiyyah alInsāniyyah fï Nazar al-Islām (Kaherah: Dar al-Salam, 1996), 13.

${ }^{21}$ Surah al-Dhariyyat (51): 56.
} 
syariat dan akidah, di mana asas ajaran agama diperkuatkan dari semasa ke semasa sama ada dalam aspek keimanan dan peribadatan. ${ }^{22}$

Jelasnya, para ulama silam sangat menjaga akidah umat dengan pelbagai penulisan dan diskusi ilmu. Misalnya Imam Abū Hanifah $(150 \mathrm{H})$, telah menulis kitab yang bertajuk al-Fiqh al-Akbar dan sebuah risalah yang diberi judul al-Bahth 'alā al-Istițā'ah ma'a al-fi'l. Penulisan ini bertujuan untuk mengkritik penyelewengan fahaman Qadariah pada waktu itu yang menular dalam masyarakat. Begitu juga Imam al-Syāfi ‘ $\bar{i}(204 \mathrm{H})$ ada menulis sebuah risalah yang bertajuk Tașhịh alNubuwwah wa al-Rad 'alā al-Barāhimah dan risalah alRad 'alā Ahl al-Ahwā yang bertujuan menolak kebatilan ajaran yang berasaskan Brahminisme dan hawa nafsu. ${ }^{23}$

Di samping ulama fekah, Imam al-Ghazāli yang terkenal sebagai hujjah al-Islām juga telah berjuang menolak fahaman Batiniah melalui bukunya Fada'ih alBäținiyyah dan al-Munqidh min al-Dalāl. Hujah-hujah yang dikemukakan oleh Imam al-Ghazāli berupaya mematahkan hujah pihak lawan yang ingin menggugat kemantapan akidah umat Islam ketika itu. ${ }^{24}$ Jelasnya, peranan yang dimainkan dalam mempertahankan akidah Islam telah berlaku sepanjang zaman sejak zaman Rasulullah s.a.w sehinggalah zaman Sahabat, Tabi'in dan selepasnya.

Mengulas peranan umara dalam penjagaan akidah ini, Imam al-Syātibi menyatakan bahawa menjaga akidah adalah sama dengan menjaga agama iaitu memberi jaminan dan amaran, dengan menguatkuasakan peraturan

${ }^{22}$ Shukri Ahmad, Pengaruh Pemikiran Ulama, 120.

${ }^{23}$ Abdul Shukor Husin, Ahli Sunah waljamaah Pemahaman Semula, 23. Lihat juga Abdul Shukor 1996, 9; al-Baghdādī, 'Abd al-Qāhir bin Țāhir, Al-Farq bayn al-Firaq (Beirut: Dar al-Afaq, t.t), 227.

24 Abdul Shukor Husin, Ahli Sunah waljamaah Pemahaman Semula, 36. Lihat juga al-Ghazāli, Abū Hāmid bin Muhammad, al-Munqidz min al-Dalāl (Beirut: Dar al-Kitab, 1979): 95, 114-116. 
tertentu ke atas masyarakat dan individu, serta memulihkan perkara-perkara yang menggugat kesucian akidah Islam. ${ }^{25}$ Manakala penulis kontemporari Arab Saudi berkenaan maqāṣid al-syari'ah iaitu Muhammad alYūbi menambah elemen jihad ke atas aspek penjagaan agama khususnya bagi memastikan syiar dan ajaran agama tidak dikesampingkan. ${ }^{26}$

Perkara sebegini bukan sahaja berlaku apabila Islam menjadi minoriti dalam politik dan sosial, malah apabila elemen sekular dan liberal mendominasi umat Islam di tengah penguasaan pemerintahan Islam. Justeru dalam memastikan akidah umat Islam terpelihara para ulama menggariskan empat perkara yang perlu dilakukan, iaitu: ${ }^{27}$

i. Jihad.

ii. Menghukum bunuh mereka yang membuat dakwaan palsu sama ada sebagai Rasul atau sebagai wakil Tuhan.

iii. Memerangi perbuatan atau amalan bidaah dan menghukum mereka supaya perkara ini tidak terus menular dalam masyarakat.

iv. Menyekat segala maksiat seperti murtad dan menghukum pelakunya sama ada di bawah hukum hudud atau hukum takzir.

Langkah cadangan yang dikemukakan adalah bagi mengekang 'negative preservation' dan kerosakan ke atas akidah dan agama umat Islam. Ini selaras dengan maksud perintah melakukan kebaikan dan perintah supaya menjauhi kemunkaran (al-amr bi al-ma'rüf wa al-nahy 'an al-munkar).

25 Abū Ishāq Ibrāhīm b. Mūsā al-Shātibī, al-Muwāfaqāt fì Ușūl alSharī'ah, ed. 'Abd-Allāh Darrāz (Beirut: Dār al-Ma'rifah, 1975, 2nd ed.), 4:27. Lihat juga March, The Maqsad of Hifz al-Din, 364

${ }^{26}$ March, The Maqsad of Hifz al-Din, 365. Lihat juga Muhammad alYūbī, Maqāsid al-Sharī'ah al-Islāmiyyah wa 'l-'alāqatuhā bi 'lAdillat al-Shar'ìyyah (Riyadh: Dār al-Hijrah, 1998), 194.

${ }^{27}$ March, The Maqsad of Hifz al-Din, 366. 
Suruhan untuk mencegah perkara penyelewengan akidah dan negatif ini juga perlu dimulakan oleh setiap anggota masyarakat itu sendiri. Berdasarkan satu hadis yang diriwayatkan daripada Huẓayfah bin al-Yamān pernah berkata yang bermaksud, "manusia sering bertanya kepada Rasulullah s.a.w mengenai amalan-amalan yang baik, tetapi aku telah bertanya tentang amalan-amalan jahat kerana aku takut ia akan menimpa diriku". ${ }^{28}$ Jelasnya, pemahaman perkara yang tidak baik oleh kalangan masyarakat dapat memberi kesedaran dan maklumat kepada mereka untuk mencegah daripada terjerumus dalam kesesatan tanpa disedari. Ini akan menghasilkan kesan kepada perbuatan makruf dan menjauhi perbuatan munkar dengan keadaan seseorang Muslim itu mempunyai ilmu. ${ }^{29}$

\section{Isu Akidah Umat Islam di Malaysia}

Orang Islam di Malaysia rata-rata adalah terdiri daripada masyarakat berbangsa Melayu, di samping orang Arab, India, Cina dan bangsa-bangsa lain. Walaupun agama Islam bagi masyarakat Melayu dan setengah masyarakat India-Muslim di negara ini telah diwarisi sejak daripada zaman nenek-moyang lagi, namun agama ini bukanlah agama asal mereka. Mengikut sejarah, masyarakat di Tanah Melayu telah diIslamkan oleh ulama yang datang dari Yaman melalui anutan yang diterima oleh para Raja dan kemudian diikuti oleh rakyat jelata. Justeru, akidah baru yang berteraskan Islam bersifat saduran ke atas agama asal yang sebelumnya berteraskan akidah dan kepercayaan kepada Hindu, Buddha dan anismisme.

Pada zaman awal ini, rakyat bukan sahaja mentaati perintah Raja dan Sultan, malah turut mentaati dan

${ }^{28}$ Diriwayatkan oleh al-Bukhārī dalam Sahihnya, Kitāb al-Fitan, j. 8, 429, hadith no. 7084.

29 Yusuf al-Qardawi, Iman dan Kehidupan, pent. Fachruddin HS (Selangor: Dewan Pustaka Fajar, 1985), 284. 
menghormati para ulama. $^{30}$ Malah para Raja-raja memuliakan ulama sebagai guru mereka sehingga ulama telah dilantik menjadi penasihat kepada Raja dan Sultan, di mana mereka adalah orang yang akan dirujuk apabila berkaitan dengan masalah agama. Pada masa yang sama, ulama diberikan kebenaran oleh pemerintah untuk mengajar ilmu-ilmu agama khususnya akidah Islam bagi memperkukuhkan keimanan masyarakat kepada agama.

Justeru, ulama memainkan peranan yang penting dalam kerajaan dan masyarakat pada zaman awal dahulu sehingga menurut Esposito, ${ }^{31}$ keberadaan ulama silam boleh dibahagikan kepada dua iaitu ulama tempatan yang bertanggungjawab kepada penanaman ideologi agama yang kukuh ke dalam masyarakat; dan ulama rasmi yang bertugas di istana atau jabatan kerajaan yang bertanggungjawab memberi penasihatan dan membantu pentadbiran bagi menyusun strategi dakwah, tarbiyyah dan menyekat ideologi asing masuk ke dalam fahaman masyarakat.

Berasaskan hubungan baik antara umara dan ulama pada zaman awal Islam di Tanah Melayu ini, ulama yang berada di samping Sultan pada ketika itu telah memberi pengaruh kepada perlaksanaan perundangan Islam. Maka tidak hairan, banyak manuskrip Melayu lama mempunyai pengaruh undang-undang Islam di samping hukum adat. Sehingga Sultan telah memerintahkan supaya para pembesar istana menulis undang-undang untuk dijadikan rujukan dalam negara dalam perkara pentadbiran dan agama, termasuk juga akidah.

Berdasarkan peranan ulama ini, maka undang-undang Kedah $^{32}$ dan kebanyakan undang-undang di negeri-negeri

${ }^{30}$ Shukri Ahmad, Pengaruh Pemikiran Ulama, 4, 13.

${ }^{31}$ Esposito, J. L., Islam and Development Religion and Socio-Political Change (New York: Syracuse University Press, 1980), 52.

${ }^{32}$ Wan Shamsudin Wan Yusof, "Hukum Kanun Kedah: Satu penelitian mengenai Hukum Kanun Dato' Kota Setar," dalam Alor Setar 250 tahun 1735-1985 (Alor Setar; Kerajaan Negeri Kedah, 1990), 56. 
di Tanah Melayu mempunyai unsur Islam yang bertindak menjaga akidah umat Islam. Dalam undang-undang Kedah misalnya, perkara syirik seperti penyembahan pokok kayu adalah disebut dengan jelas bahawa ia dilarang ke atas orang Islam. Orang yang melakukannya dikehendaki bertaubat kepada Allah. Jika engkar, mereka akan dianggap derhaka kepada Raja dan boleh dihukum dengan hukuman yang berat. ${ }^{33}$

Begitu juga dalam undang-undang di Kelantan semasa pemerintahan Sultan Ahmad (1886-1889), ${ }^{34}$ terdapat peraturan yang mengharamkan beberapa permainan budaya seperti menorah dan makyung kerana mempunyai kaitan dengan makhluk halus yang bercanggah dengan akidah Islam. Umat Islam tidak dibenarkan memainkannya walaupun ia permainan tradisional mereka kerana ia bertentangan dengan akidah Islam.

Bagaimanapun untuk menangani semua pengaruh tradisi dan adat berdasarkan perundangan awal sedikit sukar kerana faktor tradisi dan budaya nenek-moyang yang telah diamalkan dari generasi ke generasi. ${ }^{35}$ Justeru dari masa ke masa, para ulama banyak mengeluarkan fatwa dan nasihat bagi kebaikan umat Islam terutama dalam urusan harian dan keagamaan. ${ }^{36}$ Ini kerana isu keimanan adalah melibatkan soal hati dan kepercayaan yang tidaklah tetap. Malah, akidah manusia telah

33 Undang-Undang Tembera Dato' Seri Paduka Tuan. Lihat dalam Jelani Harun, Undang-undang Kesultanan Melayu dalam Perbandingan (Pulau Pinang: Penerbit USM, 2008), 166.

${ }^{34}$ Manuskrip Hukum Maksiat Kelantan. Lihat Jelani Harun, Undangundang Kesultanan Melayu, 164

${ }^{35}$ Shukri Ahmad, Pengaruh Pemikiran Ulama, 89. Lihat juga Sharifah Zaleha Syed Hassan, "From Saints to Bureucrats: A Study of the Development of Islam in the State of Kedah, Malaysia" (tesis kedoktoran, Cornell University, 1985), 83-84.

${ }^{36}$ Nagata, J., The Reflowering of Malaysia Islam, Modern Religious Redicals and Their Roots (Vancouver: University of British Press, 1984), 30. 
dinyatakan oleh nas-nas syarak sebagai sesuatu yang boleh bertambah dan boleh berkurang. ${ }^{37}$

Pada masa kini, perkara yang merosakkan akidah berlaku sama ada melalui kepercayaan kepada unsur lain yang boleh membawa kepada syirik atau berhenti beramal dengan ajaran Islam (murtad). Senario hari ini bukan kerana umat Islam mengalami kecelaruan akidah sahaja, malah ada yang ingin menukar langsung akidah dengan menjadi murtad daripada ajaran Islam. Bagi sesetengah daripada golongan ini, persoalan akidah adalah merupakan isu kebebasan beragama. $^{38}$ Sedangkan dalam Islam, seorang yang telah menerima akidah Islam tertakluk kepada syariat dan undang-undang yang ditetapkan oleh agama. Mereka diwajibkan mematuhi ajaran dan perintah agama Islam serta boleh dipaksa dalam mematuhi akidah Islam. ${ }^{39}$

Pada hari ini, persoalan yang berkait dengan akidah yang paling sensitif adalah berkenaan dengan gejala murtad. Menurut rekod Mahkamah Syariah antara tahun 2000 sehingga tahun 2010, sebanyak 863 kes telah dirujuk bagi tujuan menukar status agama Islam. Daripada bilangan ini, 168 kes telah diluluskan untuk murtad. Manakala menurut laporan portal bebas Malaysiakini, bahawa terdapat 686 permohonan tukar status agama telah dirujuk kepada pihak Mahkamah Syariah dan daripada itu, 135 kes telah diluluskan. Permohonan paling banyak yang berlaku adalah di Sabah di mana terdapat 238 permohonan

37 Surah ali Imran: 173. Surah al-Muddaththir: 31. Surah al-Taubah: 124-125. Hadith riwayat Muslim, misalnya "Iman itu lebih dari 70 atau lebih dari 60, yang paling utama adalah perkataan: "Laa Ilaaha Illa Allah" dan yang terendah adalah membersihkan gangguan dari jalanan dan rasa malu adalah satu cabang dari iman." Lihat Muslim bin Hujjaj al-Qusyayri al-Nisaburi, Sahih Muslim (Beirut: Dar Ihya' al-Kutub al-Arabiyyah, t.t.), j. 5, hadith no. 56.

38 -Abd al-Muta'al al-Sa'idi, al-Hurriyyah al-Dïniyyah (Misr: Dar alMa'arif, t.t.), 148.

${ }^{39}$ Surah al-Baqarah (2): 256. 
dan 67 permohonan telah diluluskan. Manakala di Negeri Sembilan terdapat 172 permohonan dan 33 kes daripadanya telah diluluskan.

Di Selangor, terdapat 99 permohonan tetapi tiada yang diluluskan setakat ini. Di Wilayah Persekutuan, terdapat 56 permohonan dan 10 telah diluluskan. Manakala di Perak, terdapat 47 permohonan dan 12 telah diluluskan. Sementara di Pulau Pinang, terdapat 36 permohonan dan 1 telah diluluskan. Di Melaka, terdapat 12 permohonan dan 3 telah diluluskan. Manakala di Pahang, terdapat 8 permohonan dan 7 telah diluluskan. Di Johor pula, terdapat 8 permohonan tetapi tiada yang diluluskan. Seterusnya di Kedah, daripada 5 permohonan hanya 1 diluluskan. Di Perlis, terdapat 3 permohonan dan 1 telah diluluskan. Manakala Sarawak, Terengganu dan Kelantan masing-masing terdapat 1 permohonan, ${ }^{40}$ tetapi tiada yang diluluskan. ${ }^{41}$

Menurut kajian Mohamed Azam Mohamed Adil antara tahun 2004 sehingga 2011, ${ }^{42}$ sebanyak 137 permohonan murtad telah dibuat di Mahkamah Syariah Negeri Selangor. Daripada senarai ini, 75 orang pemohon adalah berasal daripada penganut Hindu, Buddha dan Kristian, manakala 62 orang pemohon adalah daripada

${ }^{40}$ Lihat laman sesawang "Dakwah Jendela Pemikiran Ummah" yang
dilawati pada $17 \quad$ April http://www.dakwah.com.my/v1/index.php?option=com_content\&vie $\mathrm{w}=$ article \&id=372:isu-murtad-di-malaysia-perlunya-kaedahinovatif-dan-tegas \&catid=86:topik\&Itemid=357.

41 Lihat Portal Malaysiakini, "Jamil Khir: Permohonan murtad 135 orang diluluskan," http://www.malaysiakini.com/news/166920, diakses pada 17 April 2015

42 Mohamed Azam Mohamed Adil, "Isu Murtad: Mengikut Tafsiran Perlembagaan Persekutuan dan Undang-Undang Sedia Ada" (kertas kerja, Muzakarah Pakar Isu Murtad, anjuran Pejabat Mufti Negeri Selangor, 2 Julai 2009). Lihat juga Mohamad Zamri Mohamed Shapik, "Jenayah Riddah di Malaysia: Cadangan Penyelesaian berasaskan Maqasid al-Syariah," dalam Undang-undang Syariah di Malaysia (Selangor: Persatuan Ulama Malaysia, 2013), 167. 
penganut asal yang beragama Islam. Antara alasan keinginan murtad tersebut adalah kerana tidak lagi mengamalkan ajaran Islam, tidak berminat dengan agama Islam, telah dibaptiskan oleh Paderi, asuhan oleh keluarga yang beragama lain (Hindu) dan atas alasan berkahwin dengan pasangan yang beragama lain. Alasan ini menunjukkan pegangan akidah umat Islam pada akhir zaman ini semakin longgar dan sanggup berpaling dari ajaran Islam dengan jelas.

Manakala bagi masalah penyelewengan akidah yang disebabkan ajaran sesat, pihak berkuasa telah membuat 87 tangkapan berkaitan ajaran sesat antara 2007 sehingga tahun 2011. Pada tahun 2011, sebanyak lapan ajaran sesat aktif telah direkodkan berbanding tahun 2010 sebanyak sepuluh ajaran. Angka tersebut semakin menurun dari tahun sebelumnya dan ini menunjukkan bahawa penguatkuasaan undang-undang dapat dilaksanakan dengan baik. Berdasarkan jumlah ini, sebanyak 19 tangkapan dibuat pada 2007, 11 tangkapan pada tahun 2008, 40 tangkapan pada tahun 2009, 14 tangkapan pada tahun 2010 dan tiga tangkapan pada tahun 2011. Tangkapan ini adalah berdasarkan peruntukan mengenai kesalahan-kesalahan mengikut Enakmen Kesalahan Jenayah Syariah negeri-negeri. Kesalahan yang dilakukan ialah seperti pemujaan salah, doktrin palsu, mengembangkan doktrin agama, perbuatan atau perkataan murtad, subahat kepada percubaan murtad dan kesalahan dakwaan palsu. ${ }^{43}$

\section{Kawalan Undang-undang dalam Pemeliharaan Akidah} Undang-undang Malaysia mempunyai cukup peruntukan dalam memelihara akidah umat Islam. Ia bermula dengan peruntukan istimewa bagi agama Islam yang dijadikan agama bagi Persekutuan ${ }^{44}$ di mana Sultan adalah Ketua

\footnotetext{
${ }^{43}$ Lihat Hansard Dewan Negara, 13 Disember 2012, 24.

${ }^{44}$ Perkara 3 (1), Perlembagaan Persekutuan.
} 
Agama Islam bagi negeri masing-masing dan Yang Dipertuan Agong (YDPA) adalah Ketua Agama bagi negerinya dan negeri-negeri yang tidak beraja. ${ }^{45}$ Sumpah perlantikan YDPA amat jelas memberi ikrar dan janji untuk memelihara agama Islam di negara ini. ${ }^{46}$ Kedudukan ini ditambah dengan peruntukan mengenai Islam dalam Perlembagaan yang bertujuan untuk memberikan negara ini sifat dan ciri Muslim. ${ }^{47}$ Oleh itu, pemeliharaan akidah umat Islam dapat dijaga menerusi peruntukan tertinggi ini.

Berdasarkan peruntukan Perlembagaan ini, Perkara 3 (1) dan Perkara 160 (2) Perlembagaan Persekutuan dengan jelas tidak memberi hak kepada seorang Muslim untuk keluar daripada agama Islam. Justeru, orang Islam di negara ini tidak boleh menggugur atau menukar akidah mereka. Berdasarkan kes Lina Joy lawan Majlis Agama Islam Wilayah \& Anor (2004), ${ }^{48}$ walaupun Perlembagaan Persekutuan menjamin hak kebebasan beragama namun konteks ini adalah berbeza bagi seseorang yang telah memilih agama Islam sebagai agama dirinya. Seseorang itu tidak lagi boleh bertindak untuk keluar daripada agama Islam. Ini kerana dalam Islam, seorang yang keluar daripada agama adalah telah melakukan kesalahan murtad dan boleh dihukum.

Justeru, kewujudan kesalahan murtad ini menunjukkan kebebasan untuk keluar daripada agama Islam bukan lagi satu hak yang terpakai kepada umat Islam. ${ }^{49}$ Oleh kerana itu, Perlembagaan dan enakmen

\footnotetext{
${ }^{45}$ Perkara 3 (2) dan 3 (5), Perlembagaan Persekutuan.

${ }^{46}$ Perkara 37 dan Jadual Ke-4, Bahagian 1 Perlembagaan Persekutuan.

47 Abdul Aziz Bari. Malaysian Constitution: A Critical Introduction (Kuala Lumpur: Other Press, 2003), 153-156. Lihat juga Abdul Aziz Bari, Islam dalam Perlembagaan Malaysia (Petaling Jaya: Intel Multimedia and Publication, 2005), 20.

482 MLJ 119.

${ }^{49}$ Lihat juga kes Daud Mamat \& Ors lawan Majlis Agama/Adat Istiadat Kelantan \& Kerajaan Negeri Kelantan (2001) 2 MLJ 390 [MT], (2002) 3 MLJ 728 [MR].
} 
kesalahan jenayah syariah negeri-negeri telah memperuntukkan langkah pencegahan dan jenayah untuk menangani kes-kes murtad di negara ini daripada berlaku. Sementara daripada sudut pendidikan, Perlembagaan memberi kuasa yang khusus kepada Persekutuan atau negeri untuk memberi pendidikan agama Islam termasuklah di sini mata pelajaran akidah.

Kuasa ini membenarkan pihak berkuasa untuk menubuh atau menyelenggara institusi-institusi Islam atau mengadakan atau membantu dalam mengadakan ajaran dalam agama Islam dengan perbelanjaan tertentu. ${ }^{50}$ Maksud Perlembagaan ini dikembangkan lagi oleh Seksyen $50 \quad$ Akta Pendidikan $1996^{51}$ yang memperuntukkan bahawa setiap sekolah yang memiliki 5 orang pelajar yang beragama Islam hendaklah menyediakan guru untuk mengajar mata pelajaran agama Islam sekurang-kurangnya 2 jam seminggu. ${ }^{52}$

Peruntukan ini jelas dapat memastikan pelajar yang beragama Islam mendapat peruntukan pendidikan yang mencukupi bagi mendalami ilmu-ilmu Islam seperti akidah, akhlak dan syariah. Pada masa yang sama, Perlembagaan juga memperuntukkan klausa khusus yang membenarkan kerajaan negeri atau Persekutuan untuk mengawal atau menyekat daripada pengembangan apa-apa iktikad atau kepercayaan agama lain ke atas orang-orang yang menganut agama Islam. ${ }^{53}$ Berdasarkan peruntukan ini, seorang orang Melayu pernah ditahan di bawah Akta Keselamatan Dalam Negeri (ISA) kerana terlibat dalam usaha untuk mengkristiankan orang Melayu. ${ }^{54}$ Peruntukanperuntukan dan kes ini menunjukkan keseriusan

\footnotetext{
${ }^{50}$ Perkara 12 (2), Perlembagaan Persekutuan.

51 Akta 550.

${ }^{52}$ Lihat juga Peraturan-peraturan Pendidikan (Kurikulum) Kebangsaan 1997.

${ }^{53}$ Perkara 11 (4), Perlembagaan Persekutuan.

${ }^{54}$ Lihat kes Minister of Home Affairs, Malaysia \& Anor versus Jamaluddin bin Othman (1989) 1 MLJ 369, 418.
} 
Perlembagaan dalam memelihara akidah umat Islam di negara ini.

Selaras peruntukan Perkara 11 (4) Perlembagaan Persekutuan di atas tadi, beberapa buah negeri telah menggubal undang-undang yang dinamakan sebagai "Enakmen Kawalan dan Sekatan Pengembangan Agama Bukan Islam Kepada Orang Islam". ${ }^{55}$ Bagaimanapun tidak semua negeri yang mengambil inisiatif meggubal enakmen yang menyekat gejala penyebaran agama lain kepada umat Islam ini. Hanya lapan negeri yang telah menggubal Enakmen Kawalan dan Sekatan Pengembangan Agama-agama Bukan Islam iaitu Terengganu $1980,{ }^{56}$ Kelantan $1981,{ }^{57}$ Kedah $1988,{ }^{58}$ Melaka 1988, ${ }^{59}$ Selangor $1988,{ }^{60}$ Pahang $1989,{ }^{61}$ Johor $1991^{62}$ dan Negeri Sembilan $1991 .^{63}$ Sementara di Perak, enakmen ini telah pun dibentang di Dewan Undangan Negeri Perak pada tahun 1988 tetapi sehingga ke hari ini masih belum diberi tarikh kuatkuasa. ${ }^{64}$ Manakala negerinegeri lain masih tidak menggubalnya seperti Wilayah Persekutuan, Pulau Pinang, Sabah, Sarawak dan Perlis.

${ }^{55}$ Lihat Hansard Dewan Negara, 30 Julai 2013, 59.

${ }^{56}$ Enakmen No. 1 Tahun 1980. Tarikh kuatkuasa ialah pada 1 April 1986.

${ }^{57}$ Enakmen No. 11 Tahun 1981. Bagaimanapun tarikh kuatkuasa ialah pada 1 Januari 1987.

${ }^{58}$ Enakmen No. 11 Tahun 1988. Tarikh kuatkuasa ialah pada 1 Oktober 1988.

59 Enakmen No. 1 Tahun 1988. Bagaimanapun tarikh kuatkuasa ialah pada 1 Januari 1990.

60 Enakmen No. 1 Tahun 1988. Tarikh kuatkuasa ialah pada 7 Julai 1988.

${ }^{61}$ Enakmen No. 5 Tahun 1989. Tarikh kuatkuasa ialah pada 1 Mac 1990.

${ }^{62}$ Enakmen No. 12 Tahun 1991. Bagaimanapun tarikh kuatkuasa ialah pada 19 Julai 2007.

63 Enakmen No. 9 Tahun 1991. Bagaimanapun tarikh kuatkuasa ialah pada 5 April 2007.

64 Enakmen No. 10 Tahun 1988. Disiarkan dalam warta pada 27 Oktober 1988. 
Antara faktor yang dikenal pasti adalah kerana negeri-negeri ini mempunyai ramai wakil rakyat yang bukan Islam melainkan Perlis. Menurut Abdul Aziz Bari, ${ }^{65}$ alasan sesetengah negeri yang tidak menggubalnya kerana beranggapan ia bertentangan dengan kebebasan beragama adalah pandangan yang silap dan tidak berasas. Ini kerana Islam adalah agama undang-undang dan semua orang Islam adalah tertakluk kepada undang-undang Islam yang tidak membenarkan mereka menukar akidah. Walau bagaimanapun bagi pihak Kerajaan Persekutuan, beberapa langkah bagi membendung gejala ini dari terus berleluasa telah diambil, antaranya seperti berikut: ${ }^{66}$

i. melakukan pemantauan dan kajian terhadap apa jua program yang dibuat oleh organisasi atau individu tertentu yang mempunyai unsur-unsur penyelewengan terhadap agama;

ii. mengkaji dan seterusnya memfatwakan mana-mana ajaran disahkan sesat bertentangan dengan akidah Ahlul Sunnah wal Jamaah;

iii. mengadakan kerjasama dengan pihak berkuasa agama negeri bagi mengambil tindakan undangundang mengikut peruntukan yang sedia ada melalui enakmen jenayah syariah negeri-negeri dan juga dengan agensi berkaitan bagi mengambil tindakan di bawah peruntukan undang-undang dan bidang kuasa masing-masing;

iv. mengadakan majlis penjelasan akidah daripada semasa ke semasa kepada masyarakat berkenaan ancaman isu semasa akidah; dan

v. memberi kaunseling agama kepada mereka yang terlibat bagi membantu mengembalikan akidah dan kehidupan mereka dalam kehidupan normal masyarakat.

${ }_{65}^{65}$ Abdul Aziz Bari, Islam dalam Perlembagaan Malaysia, 56-57.

${ }^{66}$ Lihat Hansard Dewan Negara, 30 Julai 2013, 58. 
Di samping itu, pada masa yang sama kerjasama ditingkatkan antara Jabatan Kemajuan Islam Malaysia (JAKIM) dengan agensi-agensi berkaitan melalui jawatankuasa sedia ada. Antaranya Jawatankuasa Pemandu Menangani Ajaran Sesat Peringkat Kebangsaan (JAPAS), Jawatankuasa Penyelarasan Pendidikan Islam Kebangsaan (JAPIS), Panel Pakar Akidah (PPA) dan juga Mesyuarat Khas Isu-isu Semasa Akidah iaitu task force dan juga pasukan petugas. ${ }^{67}$ Jawatankuasa ini akan saling membekalkan maklumat dan laporan bagi memastikan pemeliharaan akidah umat Islam di negara ini dapat dipantau dan dikuatkuasakan undang-undang penecegahan sekiranya berlaku.

\section{Mekanisme Undang-undang dan Fatwa Pulau Pinang dalam Pemeliharaan Akidah}

Oleh kerana di Malaysia, bidangkuasa undang-undang mengenai agama adalah terletak pada negeri masingmasing, maka usaha yang lebih jitu dan langsung adalah dimainkan oleh negeri melalui Majlis Agama Islam, Jabatan Agama Islam, Mahkamah Syariah dan Jabatan Mufti. Berdasarkan penelitian, walaupun Pulau Pinang tidak menggubal Enakmen Kawalan dan Sekatan Pengembangan Agama-agama Bukan Islam, namun penguatkuasa sekatan ini masih boleh ditangani melalui peruntukan kesalahan jenayah syariah dan fatwa oleh Mufti Negeri.

Berdasarkan peruntukan dalam Enakmen Kesalahan Jenayah Syariah negeri Pulau Pinang tahun 1996, terdapat beberapa kesalahan yang berkaitan dengan akidah yang boleh didakwa iaitu pemujaan salah, doktrin palsu, mengembangkan doktrin agama dan dakwaan palsu. Kesalahan doktrin palsu dan kesalahan dakwaan palsu adalah berkaitan dengan segala pengajaran yang

${ }^{67}$ Lihat Hansard Dewan Negara, 30 Julai 2013, 59. 
menyeleweng daripada ajaran Islam dan menggugat kesucian akidah.

Bagi kesalahan doktrin palsu, ${ }^{68}$ Seksyen 4 memperuntukkan bahawa mana-mana orang yang mengajar atau menjelaskan apa-apa doktrin atau melaksanakan apa-apa upacara atau perbuatan yang berhubungan dengan agama Islam di mana-mana tempat, sama ada tempat persendirian atau tempat awam, adalah melakukan suatu kesalahan jika doktrin atau upacara atau perbuatan itu berlawanan dengan Hukum Syara' atau mana-mana fatwa yang sedang berkuatkuasa di Negeri Pulau Pinang, dan apabila disabitkan boleh didenda tidak melebihi lima ribu ringgit atau dipenjara selama tempoh tidak melebihi tiga tahun atau disebat tidak melebihi enam sebatan atau dihukum dengan mana-mana kombinasi hukuman itu.

Manakala bagi kesalahan dakwaan palsu pula, Seksyen 6 memperuntukkan bahawa mana-mana orang yang: (a) Mengisytiharkan dirinya atau mana-mana orang lain sebagai rasul atau nabi, Imam Mahdi atau wali, atau; (b) Menyatakan atau mendakwa bahawa dia atau manamana orang lain mengetahui peristiwa atau perkara di luar pemahaman atau pengetahuan manusia, sedangkan perisytiharan, pernyataan atau dakwaan itu adalah palsu dan berlawanan dengan ajaran Islam, adalah melakukan suatu kesalahan dan apabila disabitkan boleh didenda tidak melebihi lima ribu ringgit atau dipenjarakan selama tempoh tidak melebihi tiga tahun atau kedua-duanya. Kedua-dua hukuman yang diperuntukkan bagi kesalahan yang berkaitan dengan akidah ini adalah hukuman yang maksima berdasarkan peruntukan Akta Mahkamah Syariah (Bidangkuasa Jenayah) 1965 (Pindaan 1984). ${ }^{69}$

\footnotetext{
${ }^{68}$ Enakmen Kesalahan Jenayah Syariah (Negeri Pulau Pinang) No. 3 Tahun 1996

${ }^{69}$ Akta 355.
} 
Berdasarkan fatwa pula, Jabatan Mufti Negeri Pulau Pinang telah menerbitkan beberapa koleksi fatwa daripada tahun 1995 sehingga tahun 2012. Fatwa ini terkandung dalam tiga buah buku yang diterbitkan oleh Jabatan Mufti Negeri iaitu Himpunan Keputusan Fatwa Negeri Pulau Pinang 1995-2004, ${ }^{70}$ Fatwa-fatwa yang telah diwartakan di Negeri Pulau Pinang 1996-2014 ${ }^{71}$ dan Himpunan Keputusan Fatwa Negeri Pulau Pinang 2005-2012. ${ }^{72}$ Berdasarkan penerbitan ini, fatwa berhubung pemeliharaan akidah ini boleh dibahagikan kepada beberapa aspek iaitu ajaran sesat atau menyeleweng, buku atau penerbitan yang sesat dan menyeleweng dan perbuatan yang boleh membawa kepada murtad atau gugur akidah.

Fatwa yang paling banyak direkodkan antara aspek pemeliharaan akidah ini ialah ajaran sesat dan penerbitan buku yang boleh menyelewengkan akidah. Jelasnya antara tahun 1995 sehingga 2014, terdapat 14 ajaran sesat atau bercanggah dengan akidah Ahli Sunnah wal-Jamaah telah difatwakan sebagai menyeleweng daripada Islam. Fatwa berkenaan adalah mengenai:

1. Ajaran anti hadith (Feb 1996)

2. Ajaran Tok Mat Janggut (Muhamad bin Othman) (Jun 2000)

3. Ajaran Al-Mas (Syed Mohamad Al-Masyhor) (Dis 2000)

4. Tarekat Naqsyabandiyyah Al'Aliyyah (Dis 2000)

5. Ajaran meragukan di Permatang Kerai (April-Jun 2002)

6. Fahaman Perjalanan 21 Ladunni Rahmatullah (Ajaran Ismail Harun) (Sep 2003)

7. Ajaran Azhar bin Wahab (Nov 2003, Jan 2004)

${ }^{70}$ Cetakan ketiga: 2013.

${ }^{71}$ Cetakan kedua: 2014.

72 Tiada maklumat cetakan dan tahun. 
8. Pertubuhan Arqam melalui Syarikat Rufaqa' Corporation Sdn. Bhd. (Okt 2006, Mac 2007)

9. Ajaran Suluk di Penaga dan Pondok Upeh (Ogos 2007)

10. Ajaran Tok Husin Janggut/ Ilmu Tajalli Ahmad Laksamana (Julai 2009, April 2010)

11. Ajaran Taslim (Okt 2009, Dis 2010)

12. Amalan perbomohan Pak Mus (Sep 2010)

13. Kumpulan Black Metal (Sep 2011)

14. Syiah (Jan 1997; Mei \& Sep 2012, Mac 2014)

Ajaran-ajaran ini ada yang khusus berlaku di Pulau Pinang sahaja dan ada yang umum berlaku di seluruh negara. Ajaran menyeleweng yang khusus berlaku di Pulau Pinang sahaja ialah seperti ajaran Ismail Harun, ${ }^{73}$ ajaran Taslim di Kg Seronok, ajaran Suluk di Penaga dan di Pondok Upeh. Manakala ajaran-ajaran lain seperti ajaran al-Mas (Syed Mohamad Al-Masyhor) turut diharamkan di negeri lain seperti di Melaka. ${ }^{74}$ Ajaran oleh Tok Hussin Janggut atau Ahmad Laksamana dan Kitab Hakikat Insan pula turut diharamkan di Kedah. Seterusnya kumpulan Black Metal, mazhab Syiah, Kumpulan Arqam, Azhar Wahab (Pengasas al-Mansur Holdings Sdn. Bhd) ${ }^{75}$ dan Tarekat Naqsyabandiyyah adalah kesalahan akidah yang turut diharamkan di negeri-negeri lain di seluruh negara.

Semua ajaran ini bercanggah dengan akidah Islam yang dibina berasaskan dua kalimah syahadah dan kepercayaan kepada enam rukun Iman. Dalam ajaran sesat di atas, terdapat ajaran yang menafikan Rasulullah s.a.w sebagai rasul terakhir dengan mengaku menerima wahyu,

73 Rujukan Pewartaan: En. No. 7/ 1993, Tarikh Pewartaan: 25 September 2003.

${ }^{74}$ Diwartakan pada 12 Julai 2001, No. Ruj. PMM/0007/Jld.3(27), Akta/Enakmen: M.P.U. 6.

${ }^{75}$ Diwartakan: 7 Oct, 2004, No. Ruj. Mufti Sel. 500-2; PU. Sel. AGM, Akta/Enakmen: Sel. P.U.16. 
maksum dan dapat memberi syafaat kepada umat manusia sekarang. Keimanan kepada rasul adalah dengan menolak semua dakyah tersebut yang palsu dan bercanggah dengan ajaran agama yang sebenar. Begitu jugalah ajaran yang memuja manusia dan syaitan sehingga menjadikan mereka perantara (wasilah) untuk mendapatkan rahmat dan berkat daripada Allah S.W.T.

Malah ajaran yang berlawanan dengan apa yang terkandung dalam al-Quran dan al-Sunnah adalah menyeleweng seperti tidak perlu mendirikan solat, tidak perlu berzakat, puasa dan haji, pernikahan secara batin dan mut'ah. Oleh itu bagi mengekang ajaran sebegini, Jabatan Mufti Negeri telah mengeluarkan fatwa dan mewartakannya supaya ia dapat diketahui oleh masyarakat dan pada masa yang sama dapat dikuatkuasakan pengharamannya oleh pihak berkuasa.

Manakala bagi orang awam, perlanggaran ke atas fatwa mufti ini boleh menyebabkan pesalah demikian dikenakan dakwaan di bawah Seksyen $9^{76}$ iaitu kerana menghina atau mengingkari pihak berkuasa agama. Seksyen ini memperuntukkan bahawa mana-mana orang yang bertindak dengan cara yang menghina pihak berkuasa agama atau mengingkari, melanggar atau mempertikaikan perintah atau arahan Yang Di-Pertuan Agong sebagai Ketua Agama Islam, Majlis atau Mufti, yang dinyatakan atau diberikan melalui fatwa, adalah melakukan suatu kesalahan dan apabila disabitkan boleh didenda tidak melebihi tiga ribu ringgit atau dipenjarakan selama tempoh tidak melebihi dua tahun atau keduaduanya.

Seksyen 12 pula memperuntukkan bagi kesalahan penyebaran iaitu mana-mana orang yang memberikan, mengembangkan atau menyebarkan apa-apa pendapat tentang ajaran Islam, Hukum Syara' atau apa-apa yang

${ }^{76}$ Enakmen Kesalahan Jenayah Syariah (Negeri Pulau Pinang) No. 3 Tahun 1996. 
bertentangan dengan mana-mana fatwa yang sedang berkuatkuasa di Pulau Pinang adalah melakukan suatu kesalahan dan apabila disabitkan boleh didenda tidak melebihi tiga ribu ringgit atau dipenjarakan selama tempoh tidak melebihi dua tahun atau kedua-duanya.

Kesalahan ke atas pengikut juga boleh dikenakan di bawah klausa pemujaan salah. Kesalahan ini juga merupakan kesalahan berkaitan dengan akidah di mana Seksyen 3 memperuntukkan bahawa mana-mana orang yang memuja alam semula jadi atau melakukan apa-apa perbuatan yang menunjukkan pemujaan atau rasa hormat kepada mana-mana orang, binatang, tempat atau benda dengan apa-apa cara yang menyalahi Hukum Syara' adalah melakukan suatu kesalahan dan apabila disabitkan boleh didenda tidak melebihi tiga ribu ringgit atau dipenjarakan selama tempoh tidak melebihi dua tahun atau kedua-duanya. ${ }^{77}$ Mahkamah boleh memerintahkan supaya apa-apa alat-alat pengganti, barang atau benda yang digunakan dalam pelakuan atau yang ada kaitan dengan kesalahan yang disebut dalam subseksyen (1) dilucuthakkan dan dimusnahkan, walaupun tiada seorang pun telah disabitkan atas kesalahan itu. ${ }^{78}$

Di samping kesalahan yang berupa ajaran dan penyebaran akidah yang sesat, terdapat sesetengah daripada mereka ini menulis dakyah palsu tersebut atau mengembangkan ajaran salah ini melalui penulisan yang diterbitkan. Kajian antara tahun 1996 sehingga 2015, mendapati kira-kira sepuluh fatwa yang berkaitan penerbitan bahan yang menyeleweng daripada akidah Islam ini telah diputuskan mengikut tahun-tahun berikut, iaitu:

1. 4 buku mengenai ajaran anti hadith iaitu Hadis Satu Penilaian Semula, Hadis Jawapan Kepada Pengkritik, Pendedahan Kebenaran Adalah dari

\footnotetext{
77 Seksyen 3 (1).

${ }^{78}$ Seksyen 3 (2).
} 
Tuhanmu - Hadith di dalam al-Quran, Bacaan, The Computer Speaks - God's Message to the World (Feb 1996).

2. Buku Tiang Agama terbitan Pusat Tarbiyyah (Jun 2000).

3. 4 buku diharamkan iaitu Hakikat Sembahyang oleh Imam al-Soufi, Kumpulan Ilmu Ghaib oleh al-Aufaq (terjemahan Ustaz Masoap Suhaimi), Nur Muhammad oleh Abdul Ghani Asyukur (penterjemah) dan Ahlul Sunnah dan Syiah Sebenarnya Kristian oleh Abdullah Muhammad (Feb 2001).

4. Buku Solat Ahlul Sunnah Yang Tidak Mengikut AlQuran (Jawapan Kepada Geng Anti Ulama) Bercanggah ASWJ (Mei 2002).

5. 7 buku tulisan Rasul Dahri diperakui sebagai haram iaitu Bahaya Taqlid Buta dan Ta'sub Mazhab; Imam Syafie Mengharamkan Kenduri Arwah Tahlilan, Yasinan dan Selamatan; Amalan-amalan Bid'ah pada Bulan Sya'ban; Hukum mengenai Rokok dan Mencukur Janggut; Bahaya Tariqat Sufi/Tasawuf Terhadap Masyarakat; Setiap Bid'ah Menyesatkan; Persoalan Bid'ah dan Percanggahannya (Ogos 2003, Jan 2004).

6. Buku Dilema Umat Islam antara Hadis dan alQuran tulisan Kassim Ahmad (Okt 2005).

7. Buku Fahaman dan Amalan Ibrahim Babu a/l P.M. Kamal Bacha (Okt 2005).

8. Buku/risalah/kertas kerja Ulul Albab karangan Ismail Kassim (Okt 2009, Dis 2010).

9. Risalah Korban Agong (Jun 2010).

10. Buku Syiah, 14 Manusia Suci (Sep 2010).

Pengharaman buku-buku ini menunjukkan langkah menghapuskan punca ajaran sesat ini sehingga ke akar umbi. Ini kerana meskipun pengajarnya ditangkap ataupun telah insaf, penularan buku tersebut masih boleh 
menyelewengkan masyarakat dan memberi implikasi negatif yang berterusan kepada mereka.

Sebahagian buku yang diharamkan ini adalah selaras dengan pengharaman yang dilakukan oleh pihak Jabatan Kemajuan Islam Malaysia (JAKIM) seperti buku Tiang Agama. Menurut Bahagian Penyelidikan Jakim, ${ }^{79}$ bukubuku ini mengandungi penerangan dan fatwa yang tidak benar serta bertentangan dengan ajaran agama Islam. Misalnya, mempertikaikan kalimah syahadah yang dilafazkan oleh pengikut Ahli Sunnah wal Jamaah dan menyatakan bahawa pengikut-pengikut agama Islam yang berpegang dan mengucapkan kalimah syahadah sebagai syirik. Manakala sebahagian buku hanya diharamkan oleh Jabatan Mufti Negeri Pulau Pinang sahaja dan tidak di negeri-negeri lain seperti buku Ahlul Sunnah yang tidak mengikut al Quran (Jawapan Kepada Geng Anti Ulamak) dan buku Fahaman dan Amalan Ibrahim Babu A/L P.M Kamal Bacha. Mungkin kerana ia hanya berlaku di Pulau Pinang. Buku ini diwartakan oleh Jabatan Mufti Negeri pada 9 Mei 2002 dan 27 Oktober 2005. ${ }^{80}$

Perbuatan penerbitan ini adalah bersalahan dengan Enakmen 1996 di atas iaitu penerbitan agama yang bertentangan dengan hukum syarak. Seksyen 13 memperuntukkan bahawa mana-mana orang yang: (a) mencetak, menyiarkan, menerbitkan, merakamkan, menyebarkan atau dengan apa-apa cara lain menyebarkan apa-apa buku, risalah, dokumen atau apa-apa bentuk lain rakaman yang mengandungi apa-apa jua yang bertentangan dengan Hukum Syara'; atau (b) ada dalam miliknya apa-apa buku, risalah, dokumen atau bentuk lain rakaman sedemikian, adalah melakukan suatu kesalahan dan apabila disabitkan boleh didendakan tidak melebihi

\footnotetext{
${ }^{79}$ Mustaffa Abdul Rahman. Lihat Utusan Malaysia, 5 Ogos 1999.

${ }^{80}$ En. No. 7/ 1993 dan PU/PP 200 Jld.1.
} 
tiga ribu ringgit atau dipenjarakan selama tempoh tidak melebihi dua tahun atau kedua-duanya. ${ }^{81}$

Mahkamah boleh memerintahkan supaya mana-mana buku, risalah, dokumen atau bentuk lain rakaman yang disebut dalam subseksyen (1) dilucuthakkan dan dimusnahkan, walaupun tiada seorang pun telah disabitkan atas kesalahan berkaitan dengan buku, risalah, dokumen atau bentuk lain rakaman itu. ${ }^{82}$ Bagaimanapun kesalahan ini tidak dikenakan hukuman yang maksima yang terdapat di bawah Akta 355 sebagaimana hukuman ke atas kesalahan doktrin dan dakwaan palsu di atas.

Dalam usaha memelihara akidah umat Islam, Jabatan Mufti Negeri telah mengeluarkan fatwa yang memutuskan bahawa kalimah 'Allah' di negari ini hanya dikhususkan untuk umat Islam sahaja (Mac 2009). Fatwa ini diulang lagi dalam persoalan mengenainya pada April 2010 dan seterusnya kalimah suci yang khusus bagi agama Islam ini diwartakan pada Jun 2010 yang ia tidak boleh diguna untuk bukan Islam. Fatwa ini bagi mengelak kekeliruan umat Islam bahawa Allah s.w.t yang mereka sembah adalah Tuhan yang sama yang disembah oleh orang bukan Islam. Keadaan ini boleh mengakibatkan kekeliruan dan kemasukan fahaman liberal berhubung dengan akidah Islam. Keputusan fatwa ini merupakan satu kaedah mencegah daripada berlakunya ruang atau pintu keburukan (sad zari'ah) ke atas pegangan akidah umat Islam.

Bagi mencegah kejatuhan akidah umat Islam juga, perkara-perkara yang boleh membawa kepada kerosakan atau pencemaran akidah telah difatwakan sebagai salah dan perlu dielakkan. Misalnya fatwa yang melarang penukaran nama kepada nama bukan Islam atas alasan keluar daripada agama Islam (Mac 1995), melarang membina atau membaiki rumah ibadat bukan Islam (Okt

\footnotetext{
${ }^{81}$ Seksyen 13 (1).

${ }^{82}$ Seksyen 13 (2).
} 
1996) dan perbuatan kafir-mengkafir (Julai 1999). Begitu juga hidup dengan isteri yang bukan Islam setelah menganut Islam tidak dibenarkan (Dis 2000). Ini kerana hubungan perkahwinan mereka telah terputus (faraq). Di samping itu, fatwa juga telah mengharamkan senaman yoga yang mengandungi mantera dan ajaran agama lain (Jan 2009, Okt 2009). Fatwa-fatwa ini bertujuan untuk memelihara akidah umat Islam khususnya masyarakat umum yang mudah terpengaruh dengan agama lain, atau menganggap semua agama adalah setara. Semua ini adalah salah faham dalam akidah yang perlu dijauhi.

Fatwa-fatwa negeri Pulau Pinang jelas memandang berat gejala yang boleh meruntuhkan akidah seseorang umat Islam. Malah kedudukan orang Islam yang murtad diberi penekanan supaya mereka diberi kaunseling dan dakwah semula (Ogos 2009). Fatwa negeri dengan jelas memerintahkan supaya orang Islam yang murtad di negeri ini dikehendaki bertaubat semula (istitābah) dan melalui beberapa sesi kaunseling dan pengajaran keagamaan supaya pegangan mereka kepada agama Islam dapat dipulihkan semula dan kembali mengimani ajaran Islam (Feb 2013).

\section{Penutup}

Perbincangan menunjukkan bahawa perkara akidah adalah merupakan isu yang penting dalam keimanan seseorang Muslim. Ia menjadi titik permulaan kepada keimanan kepada Allah dan rasul-Nya. Justeru, para ulama sejak zaman rasulullah s.a.w., Sahabat dan Tabi'in sehingga ke hari ini bersepakat bahawa pemeliharaan kepada iman adalah wajib bagi menjaga kesucian agama. Penjagaan akidah juga adalah bagi memastikan syiar agama akan terus berkembang. Oleh kerana itu pada zaman awal Islam, umat Islam wajib mempertahankan akidah dengan jihad, dan tidak dibenarkan menggugurkan akidah mereka secara murtad. Mereka akan dikenakan penalti oleh syarak sebagai satu kesalahan dalam agama jika berbuat 
demikian seperti gesaan supaya bertaubat atau dikenakan hukuman bunuh.

Peri penting aspek akidah ini turut mendapat tempat dalam manuskrip awal dalam Kesultanan Melayu awal seperti di Kedah dan Kelantan. Perkara-perkara yang boleh menggugat akidah umat Islam, diperintahkan supaya dihentikan dan dijauhi. Perkara ini berterusan sehinggalah kepada penggubalan Perlembagaan Persekutuan dan undang-undang pentadbiran agama Islam di setiap negeri. Terdapat peruntukan khusus dalam Perlembagaan yang menjaga akidah umat Islam sama ada melalui institusi pendidikan mahupun daripada institusi pentadbiran dan penguatkuasaan.

Secara khusus di Pulau Pinang, pentadbiran Islam dan fatwa diuruskan seiring dengan kehendak daruri nas di mana perkara yang membawa kepada penyelewengan akidah hendaklah dibendung sama ada dengan gesaan taubat atau penguatkuasaan undang-undang. Daripada perbincangan, dua bentuk pemeliharaan akidah dilakukan di sini iaitu melalui sad al-dharā'i dan penguatkuasaan hukuman ke atas penjenayah akidah. Justeru kesalahan yang membawa kepada penyelewengan akidah dapat disekat dan ini dapat memastikan akidah umat Islam adalah terpelihara dengan baik dan sempurna.

\section{Rujukan}

Abdul Aziz Bari. Islam dalam Perlembagaan Malaysia. Petaling Jaya: Intel Multimedia and Publication, 2005. Abdul Hadi Awang. Mukaddimah Akidah Muslim. Kelantan: Pustaka Aman Press, 1991.

Abdul Shukor Husin. Penjelasan tentang Ahli Sunah

Waljamaah. Kertas Kajian, Peguam Negara Malaysia. 1996.

Abdul Shukor Husin. Ahli Sunah wal jamaah Pemahaman Semula. Syarahan Perdana Professor: Universiti Kebangsaan Malaysia, 1998. 
Al-Baghdādī, `Abd al-Qāhir bin Ṭāhir. Al-Farq bayn alFiraq. Beirut: Dar al-Afaq, t.t.

Choudhury, G. W. Islam and the Modern Muslim World. Kuala Lumpur: WHS Publications Sdn. Bhd., 1993.

Esposito, J. L. Islam and Development Religion and Socio-Political Change. New York: Syracuse University Press, 1980.

Al-Ghazālì, Abū Hāāmid bin Muḥammad. Al-Munqidz min al-Dalāl. Beirut: Dar al-Kitab, 1979.

Al-Ghirnatì al-Māliki, Ibrāhīm bin Mūsā al-Lakhmí. AlMuwāfaqāt fí Ușūl al-Sharīah. Kaherah: Dar al-Hadith, 2006.

Hawwa, Sa`ìd. Al-Asās fì al-Tafsìr. Kaherah: Dār alSalām, 1985.

Jelani Harun. Undang-undang Kesultanan Melayu dalam Perbandingan. Pulau Pinang: Penerbit USM, 2008.

March, Andrew F. The Maqsad of Hifz al-Din: Is liberal religious freedom sufficient for the Shari'ah? In Islam and Civilisational Renewal (2): 361. "The Maqsad of Hifz al-Din: Is Liberal Religious Freedom Sufficient for the Shari'ah?" In Islam and Civilizational Renewal, 2(2) (January 2011), pp. 358-378.

Mohamad Zamri Mohamed Shapik, "Jenayah Riddah di Malaysia: Cadangan penyelesaian berasaskan maqasid al-syariah." Dalam Undang-undang Syariah di Malaysia. Selangor: Persatuan Ulama Malaysia, 2013.

Mohamed Azam Mohamed Adil, "Isu Murtad: Mengikut Tafsiran Perlembagaan Persekutuan dan UndangUndang Sedia Ada" (Kertas kerja Muzakarah Pakar Isu Murtad, anjuran Pejabat Mufti Negeri Selangor).

Nagata, J. The Reflowering of Malaysia Islam, Modern Religious Redicals and Their Roots. Vancouver: University of British Press, 1984.

Al-Qurțūbì, Muḥamad bin Aḥmad al-Anșārī. Al-Jāmi' li Aḥkām al-Qur'ān. Beirut: Dar al-Kutub al-'Ilmiyyah, t.t. 
Al-Sa'idi, `Abd al-Muta`al. Al-Hurriyyah al-Dīniyyah. Misr: Dar al-Ma'arif, t.t.

Sharifah Zaleha Syed Hassan. "From Saints to Bureucrats: A Study of the Development of Islam in the State of Kedah, Malaysia." Tesis kedoktoran, Cornell University, 1985.

Al-Shātib̄̄, Abū Ishāq Ibrāhīm b. Mūsā. Al-Muwāfaqāt fì Ușūl al-Sharī'ah, ed. 'Abd Allāh Darrāz. Beirut: Dār alMa'rifah, 1975, 2nd ed.

Shukri Ahmad. Pengaruh Pemikiran Ulama di Semenanjung Malaysia Akhir Abad ke-20. Kedah: UUM Press, 2011.

'Ulwān, `Abd Allāh Nāsiḥ. Muhạạdarah Takwīn alSyakhșiyyah al-Insāniyyah fï Nazar al-Islām. Kaherah: Dar al-Salam, 1996.

Wan Shamsudin Wan Yusof. "Hukum Kanun Kedah: Satu Penelitian mengenai Hukum Kanun Dato' Kota Setar." Dalam Alor Setar 250 tahun 1735-1985. Alor Setar; Kerajaan Negeri Kedah, 1990.

Al-Yūbī, Muhammad. Maqāsid al-Sharī'ah al-Islāmiyyah wa al-'Alāqatuhā bi al-Adillat al-Shar'ìyyah. Riyadh: Dār al-Hijrah, 1998.

Ziad Muḥammad Aḥmidan. Maqāṣid al-Sharīah alIslāmiyyah. Beirut: Muassasah al-Risalah, 2008. 
Jasni, "Pemeliharaan Akidah Islam,” Afkār Vol. 18 Special Issue (2016): 1-34 